\title{
MYOCARDIAL FUNCTION IN THE FIRST THREE DAYS OF LIFE AND AT TERM IN PREMATURE INFANTS BY DIFFERENT ECHOCARDIOGRAPHIC MODALITIES
}

\author{
B.H. Eriksen ${ }^{1}$, E. Nestaas ${ }^{2}$, T. Hole ${ }^{3,4}$, A. Støylen ${ }^{5,6}$, D. Fugelseth ${ }^{7,8}$
}

${ }^{1}$ Department of Paediatrics, Sunnmore Public Health Enterprice, Alesund, ${ }^{2}$ Department of Paediatrics, Vestfold Hospital Trust, Tønsberg, ${ }^{3}$ Department of Medicine, Sunnmore Public Health Enterprice, Alesund, ${ }^{4}$ Faculty of Medicine, Norwegian University of Science and Technology, ${ }^{5}$ Department of Cardiology, St. Olavs Hospital, ${ }^{6}$ Department of Medical Imaging, Faculty of Medicine, Norwegian University of Science and Technology, Trondheim, ${ }^{7}$ Department of Neonatal Intensive Care, Oslo University Hospital HF, Ullevål, ${ }^{8}$ Faculty of Medicine, University of Oslo, Oslo, Norway

Background: Conventional echocardiographic evaluation of myocardial function is based on visual assessment and indirect indices of myocardial performance. Tissue Doppler imaging (TDI) can assess the myocardial wall motion directly.

Aims: To compare myocardial function indices in the early transitional period with the results at term in premature infants with gestational age 30-35 weeks.

Methods: Twenty-five infants with a median (range) gestational age of 33 weeks $\left(31-34^{+4}\right)$ and birth weight 1970g (1220-2836), underwent echocardiographic examination the first three days after birth and at term. Mitral and tricuspid annulus excursion were measured by M-mode (MAE, TAPSE) and colour TDI (cTDI). We also measured pulsed wave (pw) peak systolic velocities for the mitral (MV) and tricuspid (TV) annulus. The results were divided by the left ventricular length (L) to normalize for heart size, thereby obtaining strain and strain rate values for the left (LV) and the right ventricle (RV).

Results:

\begin{tabular}{|l|l|l|l|l|}
\hline & Day 1 & Day 2 & Day 3 & At term \\
\hline Strain LV (MAE/L) & $0.19(0.03) \mathrm{n}=25$ & $0.18(0.03) \mathrm{n}=24$ & $0.18(0.03) \mathrm{n}=22$ & $0.20(0.03) \mathrm{n}=23$ \\
\hline $\begin{array}{l}\text { Strain RV } \\
(\mathrm{TAPSE} / \mathrm{L})\end{array}$ & $0.29(0.06) \mathrm{n}=24$ & $0.30(0.07) \mathrm{n}=25$ & $0.30(0.06) \mathrm{n}=23$ & $0.37(0.04) * \mathrm{n}=23$ \\
\hline $\begin{array}{l}\text { Strain rate LV } \\
(\mathrm{pwMV} / \mathrm{L})(1 / \mathrm{s})\end{array}$ & $0.17(0.02) \mathrm{n}=20$ & $0.17(0.03) \mathrm{n}=20$ & $0.19(0.03) \mathrm{n}=18$ & $0.19(0.04) \mathrm{n}=20$ \\
\hline $\begin{array}{l}\text { Strain rate RV } \\
(\mathrm{pwTV} / \mathrm{L})(1 / \mathrm{s})\end{array}$ & $0.24(0.04) \mathrm{n}=20$ & $0.26(0.06) \mathrm{n}=21$ & $0.26(0.06) \mathrm{n}=18$ & $0.29(0.04) * \mathrm{n}=20$ \\
\hline $\begin{array}{l}\text { Strain LV (cTDI } \\
\text { MV/L) }\end{array}$ & $0.14(0.03) \mathrm{n}=24$ & $0.15(0.04) \mathrm{n}=24$ & $0.14(0.02) \mathrm{n}=22$ & $0.14(0.02) \mathrm{n}=22$ \\
\hline $\begin{array}{l}\text { Strain RV (cTDI } \\
\text { TV/L) }\end{array}$ & $0.24(0.06) \mathrm{n}=25$ & $0.26(0.05) \mathrm{n}=25$ & $0.26(0.06) \mathrm{n}=23$ & $0.30(0.05) * \mathrm{n}=23$ \\
\hline
\end{tabular}

[Mean (SD), * $p<0.05$ for increase at term]

Conclusions: There was a statistically significant increase in the right ventricular myocardial strain and strain rate values at term. This might be explained by the physiological decrease in right ventricular afterload. 